\title{
INCIDENCE AND SEVERITY OF WHITE MOLD FOR SOYBEAN UNDER DIFFERENT CULTURAL PRACTICES AND LOCAL METEOROLOGICAL CONDITIONS
}

\author{
INCIDENNCIA E SEVERIDADE DE MOFO-BRANCO EM SOJA SOB DIFERENTES \\ PRÁTICAS CULTURAIS E CONDIÇÕES METEOROLÓGICAS LOCAIS
}

\section{Gustavo Castilho BERUSKI ${ }^{1}$; André Belmont PEREIRA² ${ }^{2}$ David Souza JACCOUD-FILHO³; Felipe Fadel SARTORI ${ }^{4}$; Paulo Cesar SENTELHAS ${ }^{5}$}

1. Biólogo, Mestre em Agronomia, Doutorando em Engenharia de Sistemas Agrícolas, Escola Superior de Agricultura "Luiz de Queiroz"-ESALQ-USP - Piracicaba, SP, Brasil. beruskigc@usp.br; 2. Engenheiro Agrônomo, Professor, Doutor, Departamento de Ciências do Solo e Engenharia Agrícola - DESOLO - UEPG - Ponta Grossa, PR, Brasil; 3. Biólogo, Engenheiro Agrônomo, Professor, Doutor, Departamento de Fitotecnia e Fitossanidade - DEFITO - UEPG - Ponta Grossa, PR, Brasil; 4. Engenheiro Agrônomo, Mestrando em Fitotecnia, Escola Superior de Agricultura "Luiz de Queiroz" - ESALQ-USP - Piracicaba, SP, Brasil; 5. Engenheiro Agrônomo, Professor Doutor, Departamento de Engenharia de Biossistemas, Escola Superior de Agricultura "Luiz de Queiroz" ESALQ-USP - Piracicaba, SP, Brasil.

\begin{abstract}
The Sclerotinia sclerotiorum (Lib.) de Bary fungus is a necrotrophic and polyphagous pathogen with soybean crop as one of its most important hosts. However in order to occur epidemics caused by such a pathogen it is necessary that the climatic conditions, mainly air temperature and relative humidity be favorable to the occurrence and development of the disease. The current research aimed to assess the incidence and severity of S. sclerotiorum in soybean plants grown in Arapoti, PR, Brazil, as a function of different plant populations, row spacing, and microclimate. The experiment was conducted in a naturally infested area. The experimental design adopted was a randomized block in a factorial combination with 4 row spacing $(0.35,0.45,0.60,0.75 \mathrm{~m})$ and 4 plant populations $(150,200,250 ; 300$ thousand plants per hectare), totaling 16 treatments and 4 replications. Throughout the current study we performed 4 assessments of incidence and severity. Local climatic conditions were favorable for the incidence and severity of the pathogen. Mean air temperature, rainfall, relative humidity and leaf wetness duration, monitored during all experimental period, favored the development of the pathogen in the experimental field. Yield and 100 seed weight did not show fluctuations as a function of variations on the incidence and severity of white mold in soybean crop fields. Nevertheless, crop yield was higher under a reduced spacing, whereas the 100 seed weight showed the highest values under the lowest plant population treatment.
\end{abstract}

KEYWORDS: Glycine max (L.) Merrill. Sclerotinia sclerotiorum (Lib.) de Bary. Paraná State. Row spacing. Plant populations.

\section{INTRODUCTION}

Soybean is grown in Brazil on a large scale. The development of diseases is one of the greatest problems faced by growers because this can trigger significant losses in relation to yields and increased production costs of the grain and seeds, mainly due to the utilization of agrichemicals in crop fields. Among the pathogens that possess the capacity to cause diseases in soybean plants, the Sclerotinia sclerotiorum (Lib.) de Bary fungus is one of the most significant.

S. sclerotiorum is a necrotrophic and polyphagous pathogen possessing a vast spectrum of hosts, roughly 408 agricultural crops, of which the most important in terms of economic are soybean, common beans and cotton (BOLAND; HALL, 1994; BOLTON et al., 2006). This pathogen has been disseminated all over Brazil, with a large spread in the south, center-west and southeast states, and some areas of the northeast of the country (JULLIATTI et al., 2013). Moreover, the fungus in question has a natural ability to form resistance structures, named sclerotium, which can survive in the soil for a period of time, varying from 3 to 8 years, even under adverse environmental conditions (STEADMAN, 1983; BOLTON et al., 2006).

White mold is an endemic disease; however, epidemics in soybean crops are more frequent under field conditions. It is triggered mainly by meteorological conditions, particularly the microclimate generated by the plant canopy architecture and the amount of initial inoculums present on the soil surface. In short, regimes of air temperature between $5^{\circ} \mathrm{C}$ and $30^{\circ} \mathrm{C}$, high levels of relative air humidity and high water vapor concentration at the surface of the plants (recurring between 12 and 16 hours in order to produce a leaf wetness duration of 42 to 72 hours), along with the occurrence of precipitations throughout the 
flowering stage of the growing season of the crop are the main factors in the development of white mold (STEADMAN, 1983).

Microclimatic conditions inside the canopy of the crop can be modified, depending on the management practices adopted in compliance with different sowing dates, reductions in row spacing, rises in plant populations, the use of genotypes with a greater height, and usage of irrigation systems (PENNYPACKER; RISIUS, 1999). Different management practices can interfere both with the disease control measures and its intensification in production fields (WORKNEH; YANG, 2000; MILA et al., 2003; HARIKRISHNAN; DEL RIO, 2008).

Hartman et al. (1998) observed that there is an increase in the incidence of white mold when soybean is grown under small spacing, ranging from 0.25 to $0.38 \mathrm{~m}$, as opposed to spacing of $0.96 \mathrm{~m}$. Among 68 production fields of soybean, 46 were carried out under row spacing equals to $0.76 \mathrm{~m}$, and showed a disease incidence corresponding to $48 \%$. On the other hand, in the remaining 22 production fields, under spacing greater than $0.76 \mathrm{~m}$, the disease incidence was $36 \%$. Taking into consideration that $10 \%$ of disease incidence results in a reduction in soybean yields of approximately $200 \mathrm{~kg} \mathrm{ha}^{-1}$ (CHUN et al., 1987; HOFFMAN et al., 1998), enlarging spacing rows might be seen as a management practice that would favor the control of white mold for soybean.

High plant populations can also favor the occurrence and development of white mold for soybean. According to Chad et al. (2005), depletions in plant population for soybean crop is a more efficient method to control white mold compared to row spacing treatments. In addition, Mila et al. (2003) associated the high incidence and severity of $S$. sclerotiorum to high plant populations for the crop in study.

Faced with the aforementioned outcomes and observations reported in the literature, the aim of the current research was to evaluate the incidence and severity of white mold for soybean crop grown in the Paraná State, southern Brazil, in relation to plant populations, row spacing, and local meteorological variables in order to arrive at a reduction in the production costs for growers and to guarantee the sustainability of agriculture at the studied site.

\section{MATERIAL AND METHODS}

The experiment was carried out throughout the summer season of 2011-2012 at an naturally infected area located at Arapoti, in the region of Campos Gerais of the State of Paraná (altitude 966 meters, latitude $24^{\circ} 16^{\prime} \mathrm{S}$ and longitude $50^{\circ} 06^{\prime} \mathrm{W}$ ), Brazil.

Shortly before the installation of the experiment in the field, four distinct points were collected at random with an area of $0.25 \mathrm{~m}^{2}$ at a depth of $0.05 \mathrm{~m}$ to determine the amount of sclerotium in the experimental area, which was equivalent to 31 sclerotium per square meter of land (JACCOUD FILHO et al., 2010).

At the field trial the soybean cultivar used was BMX Apolo RR®. This type of genotype is susceptible to white mold and it is considered to have a super precocious cycle. The sowing date was on October $18^{\text {th }}, 2011$. Throughout the crop growing season, all the conventional cultural practices were adopted in compliance with the recommendation of expertises (EMBRAPA, 2011), except concerning the application of chemical products to control white mold.

The experimental design adopted was a randomized block distributed in a factorial combination with 4 row spacing and 4 plant populations (Table 1), totaling 16 treatments and 4 replications. The experimental units were comprised of twelve rows with a length of 10 meters and varying width, as a function of relative spacing studied.

At the experimental area, an automatic weather station from Campbell Scientific, Inc., Utah-USA was installed for monitoring the local meteorological data. Coupled to such a weather station, the sensors were responsible for the measurement of global solar radiation flux density, photosynthetically active radiation, air temperature, precipitation and relative air humidity on a daily basis. All sensors were connected to a data logger, model CR-1000®, from Campbell Scientific, Inc., that by means of a PC208W® program for Windows $®$ environment was programmed to perform readings with a frequency of 60 seconds, and storing averages every 15 minutes.

In order to estimate leaf wetness duration (LWD) a series of data collected by a HMP45C (Temperature and Relative Humidity Probe) sensor was used. The estimation method taken into account to assess LWD was the one that considers the number of hours with a relative humidity above $90 \%$ (NHRH > 90\%) (SENTELHAS et al., 2008). 
Table 1. Combination of plant population and row spacing, resulting on the number of plants per linear meter used to compose the experiment located at Arapoti, Paraná, Brazil. Cultivar BMX Apolo RR®. 2011/2012 Season.

\begin{tabular}{ccccc}
\hline \multirow{2}{*}{$\begin{array}{c}\text { Population } \\
\left(\mathbf{1 0 0 0} \text { plants ha }^{-1}\right)\end{array}$} & $\mathbf{0 . 3 5}$ & \multicolumn{4}{c}{ Row spacing $(\mathbf{m})$} \\
\cline { 2 - 5 } & \multicolumn{4}{c}{ Plants per linear meter } \\
\hline $\mathbf{1 5 0}$ & 5.25 & 6.75 & 9.00 & $\mathbf{0 . 7 5}$ \\
$\mathbf{2 0 0}$ & 7.00 & 9.00 & 12.00 & 11.25 \\
$\mathbf{2 5 0}$ & 8.75 & 11.25 & 15.00 & 18.75 \\
$\mathbf{3 0 0}$ & 10.50 & 13.50 & 18.00 & 22.50 \\
\hline
\end{tabular}

The assessments of incidence and severity were performed from the phenological stage R1, culminating with the beginning of flowering. From the R1 stage, the following dates for the assessments of incidence and severity were chosen during 2012: January $12^{\text {th }}$ (phenological stage R3), January $25^{\text {th }}$ (phenological stage R5.1), February $10^{\text {th }}$ (phenological stage R5.3) and February $24^{\text {th }}$ (phenological stage R5.5). Among the aforementioned dates only the first one was not utilized for statistical and epidemiological analyses, since there were no infection symptoms on the assessed plants in the field at that date. Furthermore, in the period between R1 and R3 disease was also not found at the experimental site.

For the assessment of the incidence of disease, the criterion based on the percentage of infected plants per plot was adopted. In order to quantify the severity of the disease, a diagrammatic scale proposed by Juliatti et al. (2013) was used for white mold.

At the end of the crop growing season, the yield and 1000 seed weight for soybean crop were evaluated. For such evaluations, four rows with a length of 4 meters and a fetch comprised of three rows were harvested in the field trial.

To determine the 1000 seed weight, samples of a hundred seeds were weighed at each plot by means of a scale with a precision of centesimal grams. Yield was obtained from the weight of all the soybean plants harvested from each useful plot. Yield data were expressed in grams and then converted into kilograms per hectare. Both yield and 100 seed weight data were corrected by taking into consideration a water content correction factor corresponding to $130 \mathrm{~g} \mathrm{~kg}^{-1}$ (13\%).

Prior to the statistical analysis, procedure data regarding incidence and severity were transformed by making use of the mathematical expression $(x+1)^{1 / 2}$ shortly before performing the variance analysis, along with the application of the
$F$ test in order to reduce the coefficients of variation for the disease data. After subjecting the disease data to the variance analysis in order to find out which treatments were significant different, Tukey's test at a 5\% confidence level was performed for comparison of treatment averages. For both statistical analyses, the statistical package Sisvar 4.0 (FERREIRA, 2011) was utilized.

\section{RESULTS AND DISCUSSION}

Once the weather station was set up within the experimental area and records of the environmental variables were taken, the local meteorological data regarding the prevailing atmospheric conditions throughout the crop growing season at the experimental site were taken during the whole cycle of the crop.

By analyzing the meteorological data throughout the soybean crop growing season, it was possible to notice that local meteorological conditions were favorable to the development of the $S$. sclerotiorum fungus at the experimental area (Table 2).

Meteorological conditions are the driving force of the infectious process that leads to the occurrence and development of a particular plant disease in production fields (ABAWI; GROGAN, 1975). However, it is crucial that the host is present in a favorable environment and turns out to be susceptible to the pathogen or also grows at the moment of susceptibility. In order for the infection to be successful, ascospores released by sclerotium of $S$. sclerotiorum need an exogenous source of energy coming from the senescent flowers and other senescent organs of the plant (ABAWI; GROGAN, 1979; BOLAND; HALL, 1988). Based on such combined biotic and abiotic factors, it has been determined that the most susceptible phenological stage of soybean plants to the occurrence of white mold is flowering and the beginning of grain filling. 
Table 2. Meteorological data collected from an automatic weather station at Arapoti, PR, Brazil, throughout the soybean crop growing season of 2011-2012; daily data averaged from a 10-day increment.

\begin{tabular}{|c|c|c|c|c|c|c|c|c|c|c|c|}
\hline \multicolumn{12}{|c|}{ * METEOROLOGICAL VARIABLES } \\
\hline $\begin{array}{l}\text { 10-Day } \\
\text { average }\end{array}$ & TMean & TMin & TMax & $\begin{array}{c}\text { RH } \\
\text { Mean }\end{array}$ & $\begin{array}{l}\text { RH } \\
\text { Min }\end{array}$ & $\begin{array}{l}\text { RH } \\
\text { Max }\end{array}$ & $\boldsymbol{P}$ & $Q g$ & $P A R$ & $L W D^{I}$ & $L W D^{2}$ \\
\hline $01-10 / 10 / 11$ & 18.5 & 13.2 & 25.3 & 77.2 & 48.8 & 95.9 & 30.0 & 17.1 & 6.9 & 92.0 & 9.2 \\
\hline $11-20 / 10 / 11$ & 16.9 & 13.0 & 22.0 & 83.2 & 62.9 & 94.7 & 114.0 & 15.1 & 6.0 & 82.3 & 8.2 \\
\hline $21-30 / 10 / 11$ & 18.2 & 18.2 & 24.9 & 72.3 & 44.5 & 93.4 & 64.0 & 19.9 & 7.8 & 53.2 & 5.3 \\
\hline $31-09 / 11 / 11$ & 17.1 & 10.1 & 25.1 & 64.8 & 33.0 & 90.4 & 0.0 & 23.5 & 9.4 & 17.2 & 1.7 \\
\hline $10-19 / 11 / 11$ & 17.4 & 13.1 & 23.6 & 77.3 & 52.3 & 93.3 & 67.8 & 18.3 & 7.4 & 41.0 & 4.1 \\
\hline $20-29 / 11 / 11$ & 20.2 & 13.9 & 27.4 & 68.7 & 37.3 & 92.0 & 31.5 & 23.3 & 9.5 & 35.0 & 3.5 \\
\hline $30-09 / 12 / 11$ & 19.5 & 14.3 & 26.5 & 74.8 & 44.4 & 93.6 & 29.5 & 21.8 & 8.8 & 49.2 & 4.9 \\
\hline $10-19 / 12 / 11$ & 19.8 & 13.9 & 26.4 & 67.5 & 38.9 & 90.4 & 24.9 & 25.4 & 10.0 & 39.2 & 3.9 \\
\hline $20-29 / 12 / 11$ & 21.2 & 15.3 & 28.5 & 67.3 & 40.9 & 86.1 & 6.9 & 23.5 & 9.4 & 21.2 & 2.1 \\
\hline $30-08 / 01 / 12$ & 19.9 & 14.5 & 26.8 & 78.4 & 49.3 & 94.7 & 45.5 & 22.6 & 8.8 & 72.3 & 7.2 \\
\hline $09-18 / 01 / 12$ & 19.3 & 16.0 & 25.1 & 86.2 & 61.0 & 95.3 & 144.5 & 17.4 & 6.7 & 141.3 & 14.1 \\
\hline $19-28 / 01 / 12$ & 19.0 & 14.9 & 25.5 & 85.4 & 61.7 & 95.6 & 16.0 & 15.7 & 6.2 & 107.5 & 10.7 \\
\hline $29-07 / 02 / 12$ & 21.6 & 14.7 & 29.2 & 67.4 & 36.8 & 90.0 & 0.0 & 25.8 & 9.7 & 26.2 & 2.6 \\
\hline $08-17 / 02 / 12$ & 20.4 & 15.4 & 27.9 & 79.4 & 48.6 & 93.7 & 74.4 & 20.9 & 7.1 & 77.5 & 7.7 \\
\hline $18-28 / 02 / 12$ & 20.8 & 16.6 & 28.0 & 83.4 & 55.3 & 95.2 & 50.3 & 18.8 & 6.2 & 112.0 & 11.2 \\
\hline $29-09 / 03 / 12$ & 21.4 & 15.0 & 30.0 & 71.0 & 35.8 & 92.2 & 0.3 & 25.0 & 9.1 & 51.0 & 5.1 \\
\hline $10-19 / 03 / 12$ & 19.7 & 14.2 & 26.9 & 76.4 & 49.1 & 93.4 & 0.0 & 18.4 & 7.4 & 49.3 & 4.9 \\
\hline
\end{tabular}

* TMean - Mean air temperature; TMin - Minimum air temperature; TMax - Maximum air temperature $\left({ }^{\circ} \mathrm{C}\right)$; $R H M e a n-\mathrm{Mean}$ air relative humidity; $R H M i n$ - Minimum air relative humidity; $R H M a x$ - Maximum air relative humidity (\%); $P$ - Precipitation (mm); $Q g$ - Global solar radiation flux density $\left(\mathrm{MJ} \mathrm{m}^{-2}\right) ; P A R$ - Photosynthetically active radiation $\left(\mathrm{MJ} \mathrm{m}^{-2}\right.$ day $\left.^{-1}\right) ; L W D(N H R H \geq 90 \%)-$ Leaf wetness duration estimated by the approach indicating that there will be wetness whenever the relative humidity is equal to or higher than $90 \%\left(\mathrm{LWD}^{-1}-\mathrm{h} 10 \mathrm{day}^{-1} ; \mathrm{LWD}^{2}-\mathrm{h} \mathrm{day}^{-1}\right)$.

Over the period of host susceptibility the local meteorological conditions were favorable to the development of the pathogen. Throughout this period, between December $30^{\text {th }}, 2011$ and February $28^{\text {th }}, 2012$, mild temperatures, high values of air relative humidity, abundant precipitations and welldistributed, low global solar radiation flux densities and high LWD were recorded from the field trial, matching those environmental conditions necessary for the disease to occur (STEADMAN, 1983).

TMean during the susceptible time for the occurrence and development of white mold for soybean was $20.2^{\circ} \mathrm{C}$, with TMin and TMax values of $15.3^{\circ} \mathrm{C}$ and $26.9^{\circ} \mathrm{C}$, respectively. Over the susceptibility period the temperature values were found to be within the ideal range of favorability for the development of the pathogen, which varied between $15^{\circ} \mathrm{C}$ and $25^{\circ} \mathrm{C}$ (ABAWI; GROGAN, 1979; BOLAND; HALL, 1988; PENNYPACKER; RISIUS, 1999; HARIKRISHNAN; DEL RÍO, 2006). Moreover, during this period of time temperatures neither reached values lower than $10^{\circ} \mathrm{C}$ nor higher than $30^{\circ} \mathrm{C}$; levels of temperature that could affect the development of the fungus and cease the progress of the disease in soybean production fields (ABAWI; GROGAN, 1979, 1975;
WEISS et al., 1980; HANNUSCH; BOLAND, 1996).

Air relative humidity higher than $80 \%$ in the environment, throughout the period in which the host is susceptible to the disease, is one of the determining factors for S. sclerotiorum development and cause disease in soybean plants and also other crops (HANNUSCH; BOLAND, 1996). At the time of the experiment the RHMean at the trial site was $80 \%$, with extreme values varying from $52.1 \%$ (RHMin) to $94.1 \%$ (RHMax).

The occurrence of precipitation throughout the susceptibility period for soybean crop, R1, raises the values of air relative humidity, is conducive to wetness over the plant tissues, increases the water availability in the soil, and reduces air and soil temperatures in such a way as to cause the microclimatic conditions to become favorable to the germination of sclerotium and the ascospore release and deposition over the crop canopy, and further penetration, thereby accelerating the progress of the disease in the host (BOLAND; HALL, 1988).

Over the entire period of analysis, only from January $1^{\text {st }}$ through February $7^{\text {th }} 2012$ there was no record of precipitation at all, whereas during the other 10-day increments, high rainfall indices, welldistributed in the experimental area, were recorded, 
with extreme values ranging from 16 to $144.5 \mathrm{~mm}$ (Table 2).

Interaction between mild temperatures and high levels of air relative humidity and precipitation resulted in high leaf wetness duration (LWD). During the time under consideration the mean LWD roughly corresponded to 90 hours. Boland; Hall (1988) determined that under field conditions the LWD necessary for the occurrence of white mold is around $39 \mathrm{~h}$. Thus, the outcomes obtained in the current study reveal that the estimated values of LWD led to environmental conditions favorable to the occurrence of white mold.

On a daily scale, the mean LWD throughout the soybean crop growing season was of 9 hours. According to Saharan; Mehta (2008), the LWD on a daily basis that will promote the development of $S$. sclerotiorum in production fields of soybean fluctuates between 12 and 16 hours. Faced with a comparative analysis, it is possible to notice that under the climatic conditions of Arapoti, PR, the LWD necessary for the occurrence and spread of white mold over the soybean crop was less than 3 hours, a fact that might be explained by the temperature, which remained within the range that favored the development of white mold for the crop and the studied site.

Global solar radiation flux densities $(Q g)$ measured during the phenological crop stage, which were favorable to the occurrence of white mold for soybean, also contributed to the fungus development in the experimental area. Low values of $Q g$ and fraction $P A R$ were obtained on the days during which precipitation was high, probably as a consequence of accentuated cloudiness at the experiment. Peltier; Grau (2008) demonstrated that soybean plants exposed to low global solar flux densities showed a high degree of incidence and severity of white mold. This is due to the fact that under a reduced exposure to solar radiation soybean plants suffer a depletion of the amount of photoassimilates, along with a significant reduction in the photosynthesis process, and therefore a proportional decline in the synthesis of phenol compounds and secondary metabolites that cause the plants to be protected; as a result they become more vulnerable to the disease (PELTIER; GRAU, 2008).

Taking into consideration the variance analysis, along with the application of the $F$ test to the experimental data of incidence of white mold for soybean, no statistical differences among treatments were obtained for any of the assessments. It has been observed by inference that alterations in row spacing and plant populations for soybean did not lead to the incidence of white mold in production fields of soybean throughout the crop growing seasons of 2011-2012 at the area. Similar results were obtained by Buzzell et al. (1993), who examined the effect of different genotypes of soybean grown under different row spacing treatments in Ontario, Canada, upon the same disease and crop studied herein.

Differently from the incidence experimental data, when ANOVA was applied to the severity of white mold data for soybean, differences between averages were obtained for one of the treatments. Nevertheless, when Tukey's test was applied to the severity data at a $5 \%$ probability level the $0.35 \mathrm{~m}$ row spacing, as well as the 200 thousand plants per hectare treatments (T1-2), showed a $42.9 \%$ mean severity, being such a combination of treatments the selected one with the lowest value among all the other studied treatments (Table 3 ).

In production fields of soybean cultivated under low plant population, plants evidenced lower leaf area index, leading to a greater circulation of air and penetration of solar radiation among the plants; as a result, this created a microclimate unfavorable to the development of the pathogen, and consequently, led to a lower severity of the disease (HEIFFIG et al., 2006).

As mentioned previously, high plant populations can also aggravate the severity of $S$. sclerotiorum in production fields of soybean. According to Mila et al. (2003) and Chad et al. (2005), a diminution in plant populations of soybean constitutes an effective management practice to control white mold at the crop level. By studying the same disease for common beans under different plant population treatments, Vieira et al. (2010) determined that the severity of white mold plummeted linearly, with a reduction of 15 to 5 plants per meter, or from 16 to 4 plants per meter

High plant populations as a cultural practice can reduce the intensity of light captured by soybean plants. Such a mitigation of solar radiation intercepted by the crop can also promote etiolation and cause plants to become more susceptible to white mold and other diseases. Faced with a reduction in solar radiation interception there will be a decline in photosynthesis and, in turn, synthesis of photoassimilates drops in such a fashion that the expression of genes responsible for the production of antifungal and phytoalexin substances is blocked (PENNYPACKER; RISIUS, 1999). 
Table 3. Tukey's test $(\alpha=0.05)$ applied to the experimental data of severity of white mold over three evaluation periods as a function of different row spacing and plant population treatments for soybean crop in Arapoti, PR, Brazil. Cultivar BMX Apolo RR®. 2011/2012 Season.

\begin{tabular}{|c|c|c|c|c|c|c|c|c|}
\hline \multicolumn{3}{|c|}{$2^{\text {nd }}$ Assessment } & \multicolumn{3}{|c|}{$3^{\text {rd }}$ Assessment } & \multicolumn{3}{|c|}{$4^{\text {th }}$ Assessment } \\
\hline Treatments* & Means & $\begin{array}{c}\text { Test } \\
\text { Results }\end{array}$ & Treatments* & Means & $\begin{array}{c}\text { Test } \\
\text { Results }\end{array}$ & Treatments* & Means & $\begin{array}{c}\text { Test } \\
\text { Results }\end{array}$ \\
\hline T 1-2 & 3.7 & $\mathrm{a}$ & T $1-2$ & 16.6 & $\mathrm{a}$ & T $1-2$ & 42.9 & $\mathrm{a}$ \\
\hline T 1-1 & 4.8 & $\mathrm{a}$ & T 1-1 & 17.5 & $\mathrm{ab}$ & T 3-1 & 69.0 & $a b$ \\
\hline T $2-3$ & 6.9 & $\mathrm{a}$ & $\mathrm{T} 1-4$ & 27.3 & $a b$ & T 3-2 & 74.9 & $\mathrm{ab}$ \\
\hline T 3-1 & 8.3 & $\mathrm{a}$ & Т 2-3 & 28.2 & $a b$ & $\mathrm{~T} 4-2$ & 75.1 & $a b$ \\
\hline T 4-4 & 7.2 & $\mathrm{a}$ & T 4-2 & 28.1 & $a b$ & $\mathrm{~T} 1-1$ & 78.0 & $a b$ \\
\hline T 3-2 & 8.4 & $\mathrm{a}$ & $\mathrm{T} 4-3$ & 31.3 & $a b$ & $\mathrm{~T} 1-3$ & 81.2 & $a b$ \\
\hline $\mathrm{T} 4-3$ & 7.4 & $\mathrm{a}$ & Т 3-3 & 33.3 & $a b$ & T 4-3 & 84.2 & $a b$ \\
\hline T 1-4 & 8.1 & $\mathrm{a}$ & Т 2-2 & 32.9 & $a b$ & T $1-4$ & 84.6 & $a b$ \\
\hline $\mathrm{T} 4-1$ & 8.6 & $\mathrm{a}$ & Т 3-1 & 32.4 & $a b$ & $\mathrm{~T} 4-1$ & 88.3 & $a b$ \\
\hline T 4-2 & 8.4 & $\mathrm{a}$ & $\mathrm{T} 1-3$ & 34.4 & $a b$ & T 3-4 & 89.8 & $a b$ \\
\hline T 2-4 & 8.6 & $\mathrm{a}$ & Т 3-4 & 36.1 & $a b$ & Т 2-1 & 89.9 & $a b$ \\
\hline T 2-1 & 8.5 & $\mathrm{a}$ & Т 2-1 & 36.7 & $a b$ & T 2-4 & 90.9 & $a b$ \\
\hline $\mathrm{T} 1-3$ & 8.9 & $\mathrm{a}$ & Т 3-2 & 42.2 & $a b$ & T 2-2 & 94.9 & $a b$ \\
\hline T 3-4 & 9.3 & $\mathrm{a}$ & T 4-1 & 42.6 & $a b$ & T 3-3 & 94.9 & $a b$ \\
\hline Т 3-3 & 9.6 & $\mathrm{a}$ & Т 2-4 & 46.6 & $\mathrm{~b}$ & T 4-4 & 97.0 & $\mathrm{~b}$ \\
\hline T 2-2 & 12.3 & $\mathrm{a}$ & T 4-4 & 51.1 & $\mathrm{~b}$ & T 2-3 & 99.9 & $\mathrm{~b}$ \\
\hline
\end{tabular}

* Row spacings are expressed by the first variation level of the treatments (1-0.35;2-0.45;3-0.60; $4-0.75 \mathrm{~m})$; plant populations are expressed by the second variation level of the treatment $\left(1-150 ; 2-200 ; 3-250 ; 4-300\right.$ thousand plants ha $\left.{ }^{-1}\right)$; Averages followed by the same letter do not differ among themselves at a level $\alpha$ of significance.

Moreover, under high plant population conditions, crop canopy will shut down earlier and consequently there will be less circulation of air within the canopy, along with an attenuation of the interception of solar radiation by the leaves and branches of the plants. Such attenuation will, in turn, raise the relative humidity in both the air and soil, and air temperature will plunge; consequently LWD will rise in such a way as to create a microclimate favorable to the development of the pathogen (NAPOLEÃO et al., 2006).

Although a low severity of the disease for soybean plants grown under low plant populations has been reported throughout the crop growing seasons of 2011-2012, it was observed in the current research a high disease severity, regardless of the row spacing and plant population treatments employed (Table 3). Such an outcome can be ascribed to the macroclimatic conditions during the crop growing season, as well as the period of susceptibility to the occurrence of white mold for the soybean crop.

The ANOVA results in conjunction with the $F$ test applied to the experimental data related both to yield and 1000 seed weight for soybean plants grown under the different treatments, showed that there was an effect of treatment on both response variables. Therefore, in order to find out which treatments performed better under such environmental condition crop data were submitted to Tukey's test at $5 \%$ probability (Table 4 ).

In compliance with Tukey's test, it was possible to verify that the soybean yield was high with a diminution of row spacing. The treatment comprised of plots with $0.35 \mathrm{~m}$ row spacing and 250 thousand plants per hectare plant population resulted in the highest attained yield, corresponding to 5,365 $\mathrm{kg} \mathrm{ha}^{-1}$. The four highest yields were associated with narrow row spacing, irrespective of the plant population adopted. According to Rambo et al. (2003) and Knebel et al. (2006), soybean yield is directly affected by a reduction in row spacing; thus the lower the spacing the higher the yield, proving that there is no competition between the soybean plants for nutrients, water and light.

Soybean yields, as well as those of other main crops grown at the region of Campos Gerais of Paraná, are influenced by the way plants are distributed in production fields. The arrangement and disposition of the plants in a way that maximizes the uptake of water, nutrients, solar radiation and atmospheric carbon dioxide will certainly minimize intraspecific competition (HEIFFIG et al., 2006). The highest yields obtained from experimental plots with the lowest row spacing are associated with an increase in leaf area index of soybean plants $-\mathrm{a}$ fact that consequently generates a rise in the interception of solar radiation, and in turn, an intensification of photosynthetic activity of 
the plants, which will therefore increase crop yield in production fields (SHAW; WEBER, 1967).

Table 4. Tukey's test $(\alpha=0.05)$ applied to the experimental data of yield $\left(\mathrm{kg} \mathrm{ha}^{-1}\right)$ and 1000 seed weight $(\mathrm{g})$ as a function of different row spacing and plant population treatments for soybean crop in Arapoti, PR, Brazil. Cultivar BMX Apolo RR®. 2011/2012 Season.

\begin{tabular}{lccccc}
\hline & Yield & & & 1000 seed weight \\
\hline Treatments* & Means & Test Results & Treatments* & Means & Test Results \\
\hline T 4-1 & 3540 & a & T 2-4 & 17.7 & a \\
T 2-4 & 3695 & a & T 1-4 & 18.2 & a b \\
T 4-2 & 3732 & a & T 4-4 & 18.4 & a b \\
T 2-2 & 3761 & a & T 3-3 & 18.5 & a b \\
T 4-4 & 3832 & a b & T 2-2 & 18.6 & a b \\
T 4-3 & 3851 & a b & T 3-4 & 18.6 & a b \\
T 2-3 & 4030 & a b & T 1-3 & 18.7 & a b \\
T 3-2 & 4074 & a b c & T 4-3 & 18.8 & a b \\
T 3-3 & 4166 & a b c & T 3-2 & 18.8 & a b \\
T 2-1 & 4314 & a b c & T 4-2 & 18.9 & b \\
T 3-4 & 4447 & a b c & T 2-3 & 18.9 & b \\
T 3-1 & 4557 & a b c & T 2-1 & 18.9 & b \\
T 1-4 & 4775 & a b c & T 1-1 & 18.9 & b \\
T 1-2 & 5093 & b c & T 4-1 & 19.2 & b \\
T 1-1 & 5124 & b c & T 3-1 & 19.2 & b \\
T 1-3 & 5364 & c & T 1-2 & SDM 1 & \\
\hline
\end{tabular}

* Row spacing are expressed by the first variation level of the treatments $(1-0.35 ; 2-0.45 ; 3-0.60 ; 4-0.75 \mathrm{~m})$; plant populations are expressed by the second variation level of the treatment ( $1-150 ; 2-200 ; 3-250 ; 4-300$ thousand plants ha $\left.{ }^{-1}\right)$; Averages followed by the same letter do not differ among themselves at a level $\alpha$ of significance.

In general, the lowest yields were obtained from the highest row spacing treatment $(0.75-\mathrm{m})$. Intermediate yields were attached to the intermediate row spacing treatment, ranging from $0.45-\mathrm{m}$ to $0.60-\mathrm{m}$. In all cases, for yield there was no dependence relationship between such a response variable and the different plant population treatments.

Napoleão et al. (2006) examined the effect of spacing and genotypes for common beans on the severity of white mold and sanity of seeds and reached the conclusion that an increase in row spacing can significantly reduce the commercial yield of common beans, owing to a diminution in plant population. According to these researchers, depending on the genotype, reductions in spacing can be conducive to a decrease in crop yield of around 500 to $600 \mathrm{~kg} \mathrm{ha}^{-1}$.

Napoleão et al. (2006) also observed that there was no difference of yields ascribed to different plant population treatments for common beans. In their work, the highest plant populations did not result in high yields, due to the pronounced occurrence of disease in production fields. In this research, the lack of relationship between different plant population levels and yield was also conditioned by a severe injury caused by the disease in the field, leading to a high severity for most of the cultural management practices considered in this study (higher than $0.75 \%$ ).

Although correlations have not been found between yield and plant population levels, several research papers have reported that soybean yield might be altered by different plant populations, mainly due to the effects of variations that can impinge upon the incidence and severity of white mold for the main crops. Chad et al. (2005) highlighted the importance of controlling white mold whenever there is no reduction in plant population treatments, as opposed to different row spacing for the aforementioned crop.

By analyzing the intensity of white mold as a function of plant population for common beans, Paula Jr. et al. (2009) found that reductions in plant population resulted in a more efficient control of the disease, and therefore increased yield. Similar results were obtained by Vieira et al. (2010). For such researchers, depletions in plant population, besides reducing the severity of white mold, remarkably increased yields for common beans in production fields.

A weak relationship between the incidence of disease in the field and marketable yield for soybean crop grown under different row spacing and plant population conditions has been found in the literature. Contradicting the outcomes reported 
in the current study, Hoffman et al. (1998) determined that increments of $10 \%$ in the incidence of white mold at soybean production fields brought about reductions of productivity that varied from 147 to $263 \mathrm{~kg} \mathrm{ha}^{-1}$. The same fact was observed by Chun et al. (1987) for soybean crop and these researchers determined that a rise of $10 \%$ in the incidence of white mold reduced soybean yield by $235 \mathrm{~kg} \mathrm{ha}^{-1}$.

By scrutinizing the data of 100 seed weight (Table 4) it has been observed that the lowest values of 1000 seed weight in most cases were obtained from the highest plant population treatment (300 thousand plants per hectare), with values varying from 17.7 to 18.4 grams. The highest masses attributed to 1000 seed weight were found under the lowest plant population treatment, with values roughly equal to 19 grams. Under low plant population conditions there will be a less intense intraspecific competition, which will translate into a more accentuated availability of nutrients and water to agricultural systems, leading the plants to incorporate the highest mass of photoassimilates into the grains (PIRES et al., 2000).

As can be seen in Table 4, the values of 1000 seed weight for soybean plants did not show any relationship with the different levels of row spacing in consideration. In accordance with Vazquez et al. (2008), variations in spatial arrangement provided by row spacing do not interfere with the 1000 seed weight for soybean crop.

Plant population for soybean is one of the main management factors that modify crop yield components. Among them, 1000 seed weight is particularly important to assess the physiological crop response to the environment (DAROISH et al., 2005). Such alterations expressed by the 100 seed weight are directly related to a great degree of competition; mainly for water, soil nutrients and solar radiation among soybean plants.

In the current research, there were no differences between the different levels of incidence and severity of white mold and 1000 seed weight. However, other researchers have reported that a high level of incidence and severity of white mold in soybean production fields reduced the 1000 seed weight. Hoffman et al. (1998) examined soybean yield in fields infected by $S$. sclerotiorum and determined that high levels of incidence of the disease might decline the 100 seed weight from 21 to 12 grams or from 16 to 13 grams, depending on the genotype.

By studying the effect of rot caused by Sclerotinia on cultivars of soybean inoculated at different crop phenological stages, Danielson et al. (2004) observed that plants inoculated by the pathogen showed average reductions of $28.6 \%$ in 1000 seed weight.

In accordance with Hoffman et al. (1998), high incidence of white mold in soybean production fields compromises seed quality, its germination, and oil content in the seeds. Such factors are intimately related to the weight of the seeds. Besides reducing the 1000 seed weight, high levels of the disease might considerately affect some production components of soybean crop (DANIELSON et al., 2004).

By studying the effect of cultural management practices on the prevalence of white mold for soybean crop grown at the center-north region of the United States, Mila et al. (2003) determined for all the studied sites that local meteorological variables throughout the crop growing season, cultural management practices, and their interactions represented $27 \%$ of the variations linked to soybean yield, owing to the incidence and severity of white mold for the studied crop. These authors reported that the environmental conditions that favor the growth and development of the crop also favor the establishment of the pathogen $S$. sclerotiorum in soybean production fields.

Field trials conducted with soybean crop in the United States by Dillard et al. over the last five years indicated that sowing date, varieties, soil and crop management practices, and soil water supply all provided significant variations on the incidence and severity of white mold for soybean; however, such factors did not affect the primary productivity of the crop (PERSONAL COMMUNICATION FIRST INTERNATIONAL MEETING OF WHITE MOLD, PONTA GROSSA, PR, BRAZIL, 2012).

Another factor that might have affected the yield and 1000 seed weight and its relationship with incidence and severity of the disease in soybean production fields at the municipality of Arapoti, PR, is related to the distribution of inoculums, i.e. sclerotium in the soil (MILA et al., 2003). It is important to mention that climatic conditions were favorable to the development of the pathogen, mainly throughout the R1 crop stage, which is susceptible to the occurrence of the disease. Thus, to a certain extent, microclimatic variations imposed by the treatments considered herein might have been masked or attenuated by the macroclimate of the studied site. 


\section{ACKNOWLEDGEMENTS}

The authors wish to thank the following: Conselho Nacional de Desenvolvimento Científico e Tecnológico (CNPq) and Ministério da Agricultura, Pecuária e Abastecimento for the financial support provided [Edital CNPq/MAPA/SDA number
BERUSKI, G. C. et al

064/2008]; Coordenação de Aperfeiçoamento de Pessoal de Nível Superior (CAPES) for the concession of the Master's scholarship to the first author; Fundação Araucária for the Productivity Fellowship in Research to the second author, and Professor Dr. Aguinaldo José Nascimento for the assistance regarding the statistical analyses.

RESUMO: O fungo Sclerotinia sclerotiorum (Lib.) de Bary é um patógeno necrotrófico, polífago que tem a planta da soja como um dos seus principais hospedeiros. Porém, para que ocorram epidemias em decorrência desse patógeno é necessário que as condições climáticas, principalmente de umidade e temperatura do ar, sejam favoráveis para a ocorrência e o desenvolvimento da doença. O presente trabalho teve como objetivo avaliar a incidência e severidade de S. sclerotiorum em plantas de soja cultivadas em Arapoti, PR, Brasil, em função de diferentes densidades populacionais, espaçamentos entrelinhas e microclima. $\mathrm{O}$ experimento foi conduzido em área naturalmente infestada. $\mathrm{O}$ delineamento experimental adotado foi o de blocos casualizados em esquema fatorial, combinando 4 espaçamentos entrelinhas $(0,35$; 0,$45 ; 0,60 ; 0,75$ metros) e 4 densidades populacionais $\left(150,200,250,300 \text { mil plantas }^{-1}\right)^{-1}$, totalizando 16 tratamentos e 4 repetições. Ao longo do experimento foram efetuadas 4 avaliações de incidência e severidade. A temperatura média do ar, precipitação, umidade relativa do ar e a duração do molhamento foliar, monitoradas durante todo o período experimental, foram favoráveis para o desenvolvimento do patógeno na área experimental. A produção e a massa de 1000 grãos não apresentaram oscilações em função das variações nos níveis de incidência e severidade de mofo-branco na cultura da soja cultivada na condição climática estudada. Contudo, a produtividade da cultura foi maior nos tratamentos com espaçamentos reduzidos. Já a massa de 1000 grãos apresentou maiores valores em tratamentos com reduzida densidade populacional.

PALAVRAS-CHAVE: Glycine max (L.) Merrill. Sclerotinia sclerotiorum (Lib.) de Bary. Estado do Paraná. Espaçamento entrelinhas. Densidade populacional.

\section{REFERENCES}

ABAWI, G. S.; GROGAN, R. G. Epidemiology of diseases caused by Sclerotinia species. Phytopathology, St. Paul, v. 69, p. 899-904. 1979.

ABAWI, G. S.; GROGAN, R. G. Source primary inoculums and effects of temperature and moisture on infection of beans by Whetzelinia sclerotiorum. Phytopathology, St. Paul, v. 65, p. 300-309. 1975.

BOLAND, G. J.; HALL, R. Epidemiology of Sclerotinia stem rot of soybean in Ontario. Phytopathology, St. Paul, v. 78, p. 1241-1245. 1988.

BOLAND, G. J.; HALL, R. Index of plants hosts of Sclerotinia sclerotiorum. Canadian Journal Plant Pathology, Guelph, v. 16, p. 93-108. 1994.

BOLTON, M. D.; BART, P. H. J.; THOMMA, B. P. H. J.; NELSON, B. D. Sclerotinia sclerotiorum (Lib.) de Bary: biology and molecular traits of a cosmopolitan pathogen. Molecular Plant Pathology, London, v. 7, p. 1-16. 2006. http://dx.doi.org/10.1111/j.1364-3703.2005.00316.x

BUZZELL, R. I.; WELACKY, T. W.; ANDERSON, T. R. Soybean cultivar reaction and width effect on Sclerotinia stem rot. Canadian Journal of Plant Science, Ottawa, v. 73, p. 1169-1175. 1993.

http://dx.doi.org/10.4141/cjps93-156

CHAD, D. L.; RENNER, K. A.; PENNER, D.; HAMMERSCHMIDT, R.; KELLY, J. D. Glyphosate-resistant soybean management system effect on Sclerotinia stem rot. Weed Technology, Lawrence, v. 19, p. 580-588. 2005. http://dx.doi.org/10.1614/WT-04-120R2.1 
CHUN, D.; KAO, L. B.; LOCKWOOD, J. L. Laboratory and field assessment of resistance in soybean to stem rot caused by Sclerotinia sclerotiorum. Plant Disease, St. Paul, v. 71, p. 811-815. 1987.

DANIELSON, G. A.; NELSON, B. D.; HELMS, T. C. Effect of Sclerotinia stem rot on yield of soybean inoculated at different growth stages. Plant Disease, St. Paul, v. 88, p. 297- 300. 2004.

DAROISH, M.; HASSAN, Z.; AHAD, M. Influence on planting dates and plant densities on photosynthesis capacity, grain and biological yield of soybean [Glycine $\max (\mathrm{L}$.) Merr.] in Karaj, Iran. Journal of Agronomy, New York, v. 4, p. 230-237. 2005.

EMBRAPA. Empresa Brasileira de Pesquisa Agropecuária. Centro Nacional de Pesquisa da Soja. Tecnologias de Produção de Soja - Região Central do Brasil 2012 e 2013. Londrina: EMBRAPA - Soja, 2001. 262 p.

FERREIRA, D. F. Sisvar: a computer statistical analysis system. Ciência e Agrotecnologia (UFLA), Lavras, v. 35, n.6, p. 1039-1042, 2011.

HANNUSCH, D. J.; BOLAND, G. J. Influence of air temperature and relative humidity on biological control of white mold of beans (Sclerotinia sclerotiorum). Phytopathology, St. Paul, v. 86, p. 156-162. 1996.

HARIKRISHNAN, R.; DEL RÍO, L. E. A logistic regression model for predicting risk of white mold incidence on dry bean in North Dakota. Plant Disease, St. Paul, v. 92, p. 42-46. 2008.

HARIKRISHNAN. R.; DEL RÍO, L. E. Influence of temperature, relative humidity, ascospore concentration and length of drying of colonized dry bean flowers on white mold development. Plant Disease, St. Paul, v. 90, p. 946-950. 2006.

HARTMAN, G. L.; KULL, L.; HUANG, Y. H. Occurrence of Sclerotinia sclerotiorum in soybeans fields in east-central Illinois and enumeration of inocula in soybean seed lots. Plant Disease, St. Paul, v. 82, p. 560-564. 1998.

HEIFFIG, L. S.; CÂMARA, G. M. S.; MARQUES, L. A.; PEDROSO, D. B.; PIEDADE, S. M. S. Fechamento e índice de área foliar da cultura da soja em diferentes arranjos espaciais. Bragantia, Campinas, v. 65, p. 285295. 2006. http://dx.doi.org/10.1590/S0006-87052006000200010

HOFFMAN, D. D.; HARTMAN, G. L.; MUELLER, D. S.; LEITZ, R. A.; NICKELL, C. D.; PEDERSEN, W. L. Yield and seed quality of soybean cultivars infected with Sclerotinia sclerotiorum. Plant Disease, St. Paul, v. 82, p. 826-829. 1998.

JACCOUD FILHO, D. S.; MANOSSO NETO, M.; VRISMAN, C. M.; HENNEBERG, L.; GRABICOSKI, E. M. G.; PIERRE, M. L. C.; BERGER NETO, A.; SARTORI, F. F.; DEMARCH, V. B.; ROCHA, C. H.. Análise, distribuição e quantificação do "mofo branco" em diferentes regiões produtoras do estado do Paraná. In: XXXI Reunião de Pesquisa de Soja da Região Central do Brasil, Resumos... Brasília, DF. p.226-228. 2010.

JULIATTI, F. C.; CRATO, F. F.; JULIATTI, C.; COUTO, K. R.; JULIATTI, B. C. M.. Escala diagramática para avaliação da severidade de mofo branco em soja. Bioscience Journal, Uberlândia, v. 29, p. 676-680. 2013.

KNEBEL, J. L.; GUIMARAES, V. F.; ANDREOTTI, M.; STANGARLIN, J. R. Influência do espaçamento e população de plantas sobre doenças de final de ciclo e oídio e caracteres agronômicos em soja. Acta

Scientiarum Agronomy, Maringá, v. 28, p. 385-392. 2006.

MILA, A. L.; CARRIQUIRY, A. L.; ZHAO, J.; YANG, X. B. Impact of management practices on prevalence of soybean Sclerotinia stem rot in the north-central United States and on farmers' decisions under uncertainty.

Plant Disease, St. Paul, v. 87, p. 1048- 1058. 2003. 
NAPOLEÃO, R.; CAFÉ-FILHO, A. C.; LOPES, C. A.; NASSER, L. C. B. Efeito do espaçamento e da cultivar de feijoeiro sobre a intensidade do mofo-branco e a sanidade de sementes. Summa Phytopathologica, Botucatu, v. 32, p. 63-66. 2006.

PAULA JUNIOR, T. J.; VIEIRA, R. F.; ROCHA, P. R. R.; BERNARDES, A.; COSTA, E. L.; CARNEIRO, J. E. S.; VALE, F. X. R.; ZAMBOLIM, L. White mold intensity on common bean in response to plant density, irrigation frequency, grass mulching, Trichoderma spp., and fungicide. Summa Phytopathologica, Botucatu, v. 35 , p. $44-48.2009$.

PELTIER, A. J.; GRAU, C. R. The influence of light on relationships between Sclerotinia stem rot of soybean in field and controlled environments. Plant Disease, St. Paul, v. 92, p. 1510-1514. 2008.

PENNYPACKER, B. W.; RISIUS, M. L. Environmental sensitivity of soybean cultivars response to Sclerotinia sclerotiorum. Phytopathology, St. Paul, v. 89, p. 618-622. 1999.

PIRES, J. L. F.; COSTA, J. A.; THOMAS, A. L.; MAEHLER, A. R. Efeito de populações e espaçamentos sobre o potencial de rendimento da soja durante a ontogenia. Pesquisa Agropecuária Brasileira, Brasília, v. 35, p. 1541-1547. 2000. http://dx.doi.org/10.1590/S0100-204X2000000800006

RAMBO, L.; COSTA, J. A.; PIRES, J. L. F.; PARCIANELLO, G.; FERREIRA, F. G. Rendimento de grãos da soja em função do arranjo de plantas. Ciência Rural, Santa Maria, v. 33, p. 405-411. 2003. http://dx.doi.org/10.1590/S0103-84782003000300003

SAHARAN, G. S.; MEHTA, N. Sclerotinia Diseases of Crop Plants: Biology, Ecology and Disease Management. New York. Springer Science. 2008. http://dx.doi.org/10.1007/978-1-4020-8408-9

SENTELHAS, P. C.; DALLA MARTA, A.; ORLANDINI, S.; SANTOS, E. A.; GILLESPIE, T. J.; GLEASON, M. L.. Suitability of relative humidity as an estimator of leaf wetness duration. Agricultural and Forest Meteorology, Amsterdan, v. 48, p. 392-400. 2008.

SHAW, R. H.; WEBER, C. R. Effects of canopy arrangements on light interception and yield of soybeans. Agronomy Journal, Madison, v. 59, p. 155-159. 1967.

http://dx.doi.org/10.2134/agronj1967.00021962005900020009x

STEADMAN, J. R. White mold - A serious yield limiting disease of bean. Plant Disease, St. Paul, v. 67, p. 346-350. 1983.

VAZQUEZ, G. H.; CARVALHO, N. M.; BORBA, M. M. Z. Redução na população de plantas sobre a produtividade e a qualidade fisiológica da semente de soja. Revista Brasileira de Sementes, Londrina, v. 30, p. 1-11. 2008. http://dx.doi.org/10.1590/S0101-31222008000200001

VIEIRA, R. F.; PAULA JÚNIOR, T. J.; TEIXEIRA, H.; CARNEIRO, J. E. S. White mold management in common bean by increasing within-row distance between plants. Plant Disease, St. Paul, v. 94, p. 361-367. 2010.

WEISS, A.; KERR, E. D.; STEADMAN, J. R. Temperature and moisture influences on development of white mold disease (Sclerotinia sclerotiorum) on Great Northern beans. Plant Disease, St. Paul, v. 64, p. 757-759. 1980.

WORKNEH, F.; YANG, X. B. Prevalence of Sclerotinia stem rot of soybean in north central United States in relation to tillage, climate, and latitudinal positions. Phytopathology, St. Paul, v. 90, p. 1375-1382. 2000. 